\title{
Mineralogy of a Radioactive-Rare Earth Elements Occurrence in the Paleozoic Batholith, South-Central Chile
}

\author{
Santiago Collao ${ }^{*}$, Fredy Stange ${ }^{2}$, Laura Hernández², Mónica Uribe² \\ ${ }^{1}$ Departamento Ciencias de la Tierra, Universidad de Concepción, Concepción, Chile \\ ${ }^{2}$ Instituto de Geología Económica Aplicada (GEA), Universidad de Concepción, Concepción, Chile \\ Email:*scollao@udec.cl
}

How to cite this paper: Collao, S., Stange, F., Hernández, L. and Uribe, M. (2019) Mineralogy of a Radioactive-Rare Earth Elements Occurrence in the Paleozoic Batholith, South-Central Chile. International Journal of Geosciences, 10, 632-651. https://doi.org/10.4236/ijg.2019.106036

Received: May 11, 2019

Accepted: June 23, 2019

Published: June 26, 2019

Copyright () 2019 by author(s) and Scientific Research Publishing Inc. This work is licensed under the Creative Commons Attribution International License (CC BY 4.0).

http://creativecommons.org/licenses/by/4.0/

\begin{abstract}
South-central Chile has some potential mineral resources including radioactive and rare earth elements (REE) minerals. This study reports some basic characteristics of the mineralogy of a radioactive-rare earth elements occurrence, related to a pegmatitic outcrop "Vertientes Pegmatite" hosted on Paleozoic granitic rocks of the South Coastal Batholith and discusses potential areas for REE deposits, particularly beach placers along the coastline of the BioBío region. In this pegmatite, $\mathrm{X}$-ray diffraction analysis shows uraniumbearing minerals such as coffinite and metaschoepite, along with microcline, anorthoclase, albite, quartz and illite. Through optical microscopy and electron probe micro-analyzer (EPMA), rare earth minerals (monazite and xenotime) and radioactive minerals (thorite and thorium silicate \pm uranium) were identified. Additionally, granitic rocks of the South Coastal Batholith around this pegmatite show rare earth minerals (monazite and allanite).
\end{abstract}

\section{Keywords}

Radioactive-Rare Earth Elements, Mineralogy, Pegmatite, Paleozoic Batholith, South-Central Chile

\section{Introduction}

The rare earth elements (REE) are a group of 17 chemically similar elements (the lanthanides, scandium (Sc), and yttrium (Y)) [1]. Developed economies consider some members of this group to be strategic [2], as they are vital components of modern technology (e.g., high-strenght magnets used in wind turbines, hard disk drives, engines in electric cars, smartphone screens and batteries [3] [4]). 
Aside from China, which currently leads the rare earths production $(120,000$ metric tons in 2018), only ten other countries largely produce rare earths. Among them, Australia occupies the first place (20,000 tons in 2018), followed by United States, Burma (Myanmar), Russia, India, Brazil, Burundi, Thailand, Vietnam and Malaysia [6].

Reserves of REE (metric tons) are mainly found in China (44,000,000), Brazil $(22,000,000)$, Vietnam $(22,000,000)$, Russia $(12,000,000)$, India $(6,900,000)$, Australia $(3,400,000)$ and United States $(1,400,000)$ [5], and other countries such as South Africa $(860,000)$, Canada $(830,000)$, Malawi $(140,000)$ and Malaysia $(30,000)$ [6]. In Chile, information about REE ocurrences has increased over the last years due to work of some private companies, as well as studies generated by state research centers. These centers include the Chilean National Mining Corporation (ENAMI), Chilean Nuclear Energy Commission (CChEN) and National Geology and Mining Service (SERNAGEOMIN). The most relevant occurrences (rare earths and uranium) are three mining projects evaluated by ENAMI and CChEN [2]: Sierra Áspera, Cerro Carmen and Veracruz, in the Coastal Range of the Atacama region, northem Chile. Cerro Carmen, a Skarn deposit related to Cretacic intrusive and volcanic rocks, is considered the most attractive for exploitation. The main minerals found in this deposit are REE, iron-titanium, uranium and thorium oxides, with high concentrations of heavy rare earth elements (HREE), particularly yttrium (140 ppm), dysprosium (20 ppm), holmium (5 ppm), erbium (21 ppm) and ytterbium (36 ppm). The total resources are 8203 tons of REE, with indicated resources of 2944 tons (grade of $\sim 760 \mathrm{ppm}$ ), and 1811 tons of uranium.

The only project in south-central Chile is privately owned by BioLantanidos Mining. The company is currently evaluating the exploitation of a REE deposit (El Cabrito Project) by means of a pilot processing plant, located within the Coastal Range of the BioBío region (Figure 1). This project is located within an ion-adsorption clay deposit resulting from intense meteorization on Paleozoic granitic rocks [7]. By the end of 2016, more than $1000 \mathrm{~m}$ of drill holes were made, with an average depth of $50 \mathrm{~m}$. The studies made by BioLantanidos Mining indicate grades between 200 and $3000 \mathrm{ppm}$ of REE, where $40 \%$ of them are HREE. The enriched areas are soil profiles (thicknesses of $10-15 \mathrm{~m}$ ) over non-weathered granitic rocks and under leached surficial clays [2].

Surface mappings have been made in order to detect radioactive areas in the BioBío region since 2009, mainly using a portable gamma-ray integration spectrometer [8] [9] [10]. Chemical analyzes from areas with high radioactivity showed high concentrations of REE [10], which has been a motivation in studying the mineralogy of the area in which these elements are found. Thus, the main goal of this research is to determine the mineralogy of a rare earth elements occurrence in the Coastal Range of south-central Chile, specifically "Vertientes pegmatite" (Figure 1) and the granitic host rock. The secondary goal is to discuss potential zones for REE deposits exploration in this area of Chile, specifically beach placers. 


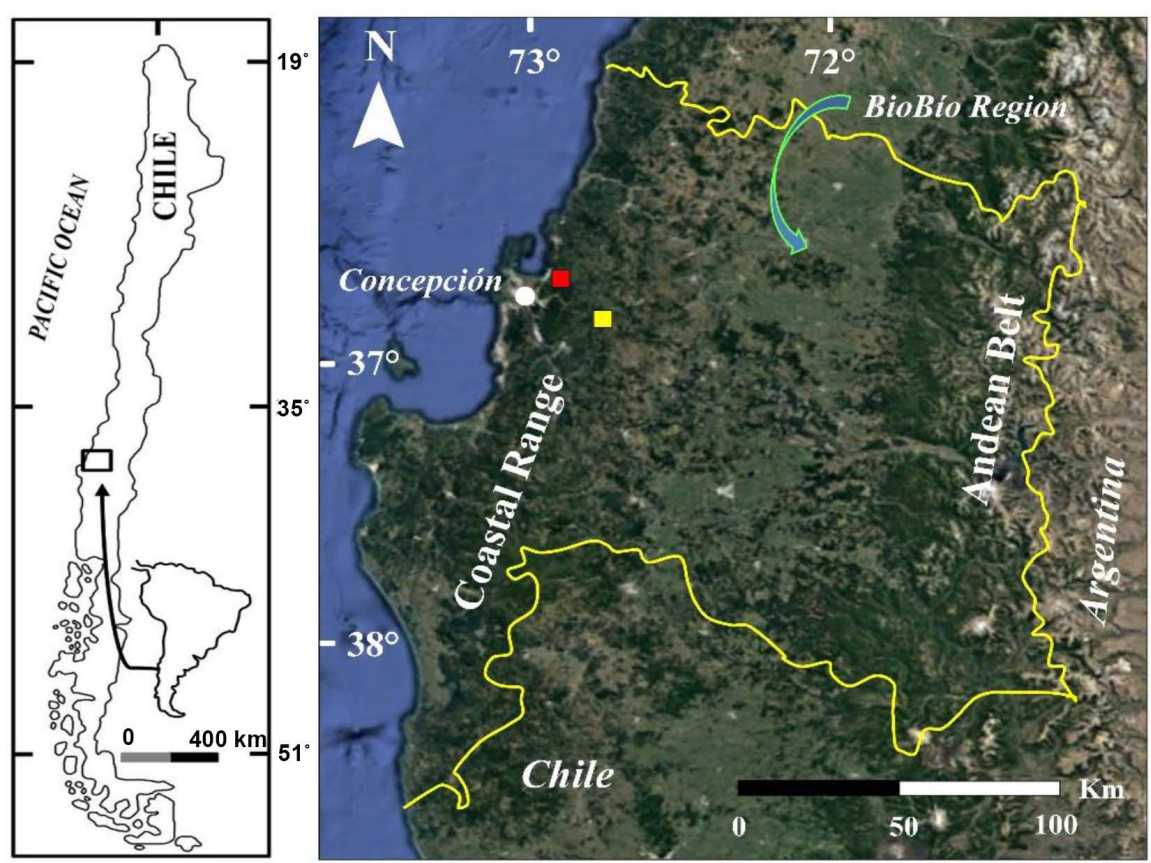

Figure 1. REE ocurrences in the BioBío region, south-central Chile. Red square: location of El Cabrito project [7]; yellow square: location of the Vertientes pegmatite.

\section{Geological Setting}

\subsection{Regional Geology}

The basement of the Coastal Range of south-central Chile is mainly composed of Paleozoic metamorphic and intrusive rocks (Figure 2). The metamorphic rocks have been divided into two strips, the Western and Eastern Series [11] [12], which are interpreted as an accretionary complex of Carboniferous to late Triassic age [13] [14]. The Western Series consists of mica schists, metabasites, metacherts and serpentinites [12], whereas the Eastern Series is composed of phyllites, slates, schists and gneisses [15] [16].

Most of the granitic rocks belong to the South Coastal Batholith $\left(32^{\circ} 30^{\prime} \mathrm{S}\right.$ $38^{\circ} \mathrm{S}$; [17]). This intrusive body is composed of calc-alkaline granitoids [18], mostly granodiorites, tonalites and granites [12] [18], which intrude the metamorphic rocks (Figure 3) and have been dated between 316 and $300 \mathrm{Ma}$ [19] [20] [21]. In addition, minor outcrops of Upper Triassic plutonic rocks (mainly monzogranite; [15]) are present in the coastal area (Figure 2).

The Mesozoic sedimentary rocks are represented by the Santa Juana Formation (Triassic; [22] [23]), composed mainly of arkosic sandstones, shales and claystones of marine-continental origin, and the Quiriquina Formation (Cretaceous; [24]), formed by marine fossiliferous sandstones and intercalations of conglomerate [25]. The Cenozoic sedimentary cover comprises marine and continental deposits which are a product of transgression and regression episodes, occurring until the Quaternary (Figure 3), within a forearc basin over a continental shelf [26]. The main sedimentary rocks of these deposits are sandstones, claystones and siltstones [27]. 


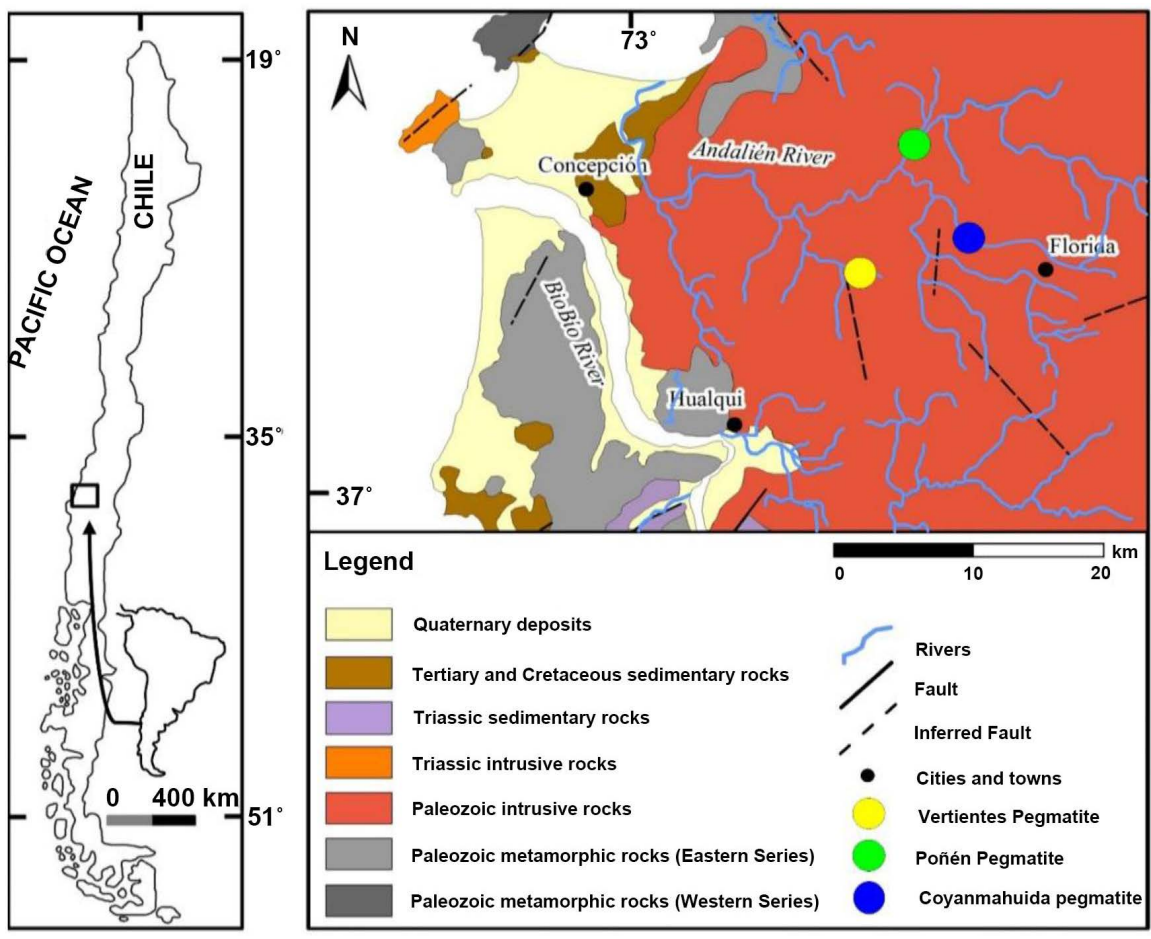

Figure 2. Geological setting (adapted from [28] [29]) and location of Vertientes, Poñén and Coyanmahuida pegmatites.

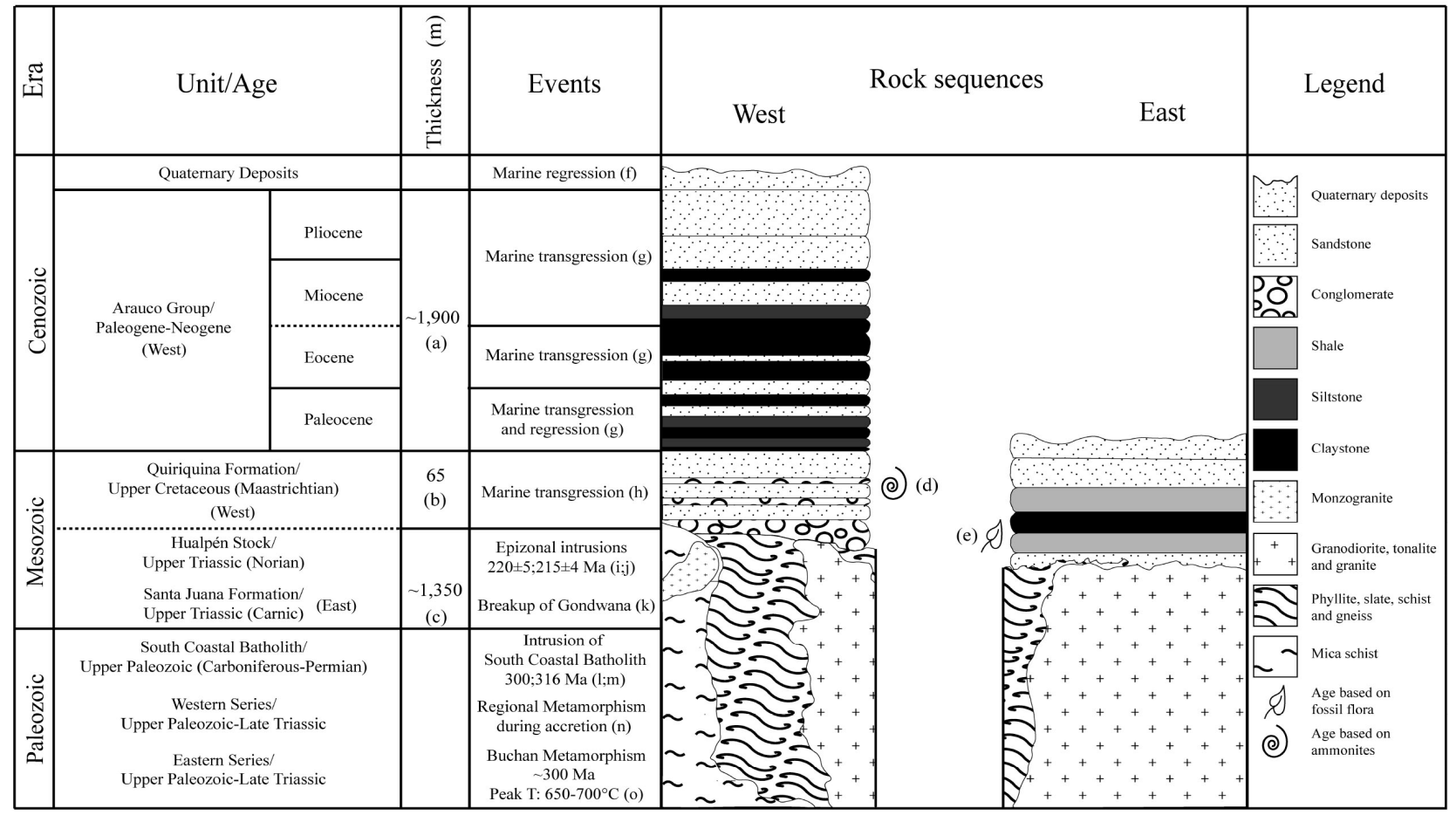

Figure 3. Simplified Upper Paleozoic to Quaternary rock sequences in the Coastal Range of the BioBío region. Two representative sections ("West" and "East") are shown, along with thickness of sedimentary units and a summary of major geological events (excluding the Western Series), where dotted horizontal lines represent significant unconformities. Geochronology data is based on the Rb/Sr whole-rock method. (a): [27]; (b): [25]; (c): [22]; (d): [24]; (e): [23]; (f): [26]; (g): [27]; (h): [30]; (i): [15]; (j): [31]; (k): [32]; (l): [20]; (m): [19]; (n): [18]; (o): [31]. 


\subsection{Local Geology}

The main lithologies of the South Coastal Batholith in the study area are coarse grained biotite/amphibole-biotite granodiorites and medium to coarse grained biotite granites (Figure 4(a) and Figure 4(b); [29]). Within this intrusive body, minor amounts of microgranites and pegmatites [17] are present. This is the case of the Vertientes pegmatite, located approximately $20 \mathrm{~km}$ SE of Concepción, close to other pegmatite outcrops (Poñén and Coyanmahuida pegmatites; Figure 2).

The Poñén and Coyanmahuida pegmatites have been dated at $310.8 \pm 1.8 \mathrm{Ma}$ and $318 \pm 15 \mathrm{Ma}$, respectively, by means of U-Pb zircon method at the University of Arizona, USA [33]. The Vertientes pegmatite shows abundant K-feldspar and plagioclase, both altered to clays (Figure 4(c)), similar to the outcrops of the Coyanmahuida pegmatite, whereas the Poñen pegmatite has a relatively bigger quantity of biotite, muscovite, microcline, quartz and less plagioclase [33]. Furthermore, the Vertientes pegmatite shows almandine garnet $(\sim 3 \%)$, generally as subhedrals crystals of $3 \mathrm{~mm}$ to $5 \mathrm{~cm}$ long (Figure 4 (d)).

In the Poñén pegmatite, where the first signs of radioactive elements were detected in this area of country, the mineralization is related to metaautunite and
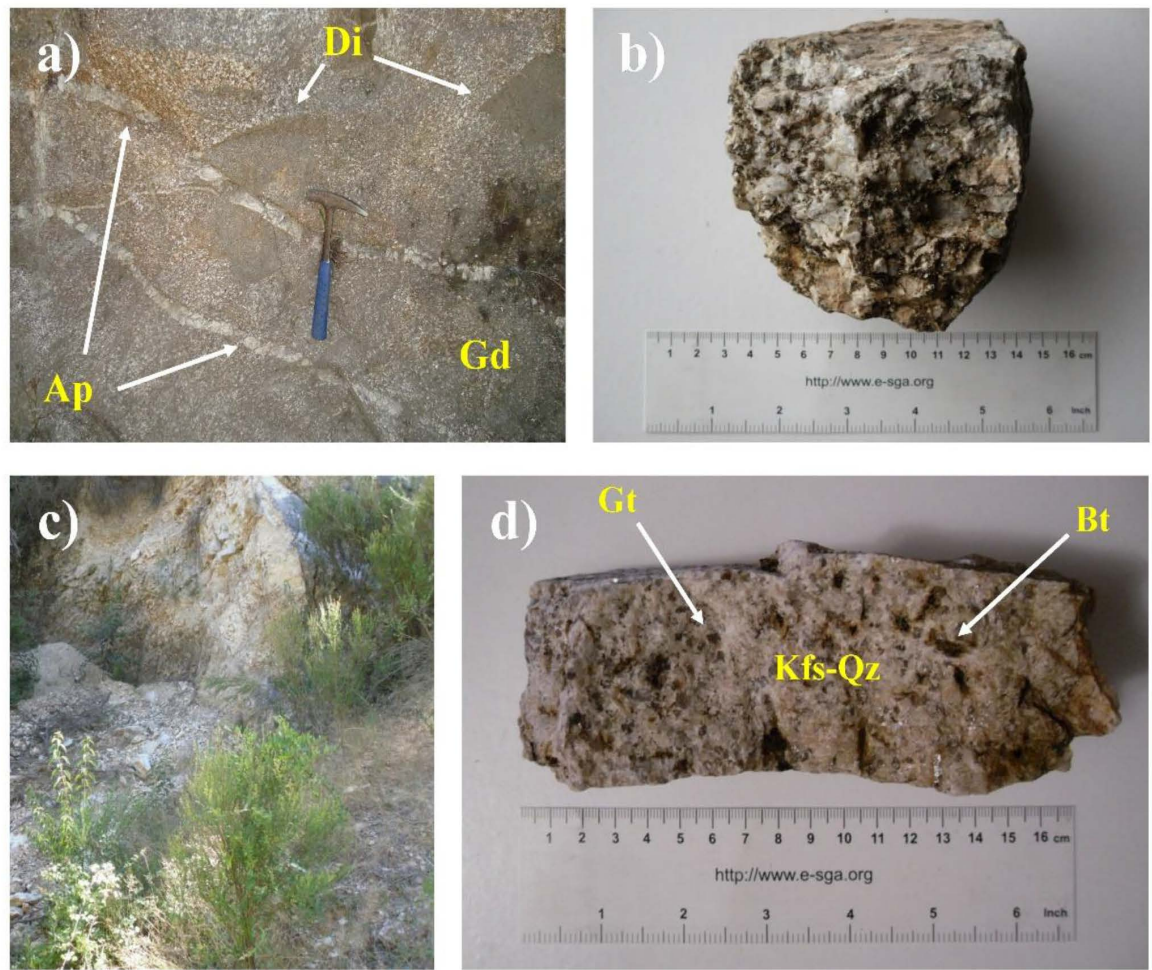

Figure 4. Intrusive bodies in the area of study. (a) South Coastal Batholith outcrop, close to the Vertientes pegmatite, showing coarse grained biotite granodiorite (Gd) with subangular fine grained diorite xenoliths (Di) cut by aplite dikes (Ap). (b) Hand sample of the granodiorite in (a). (c) Vertientes pegmatite outcrop, where feldspars are strongly altered to clays. (d) Hand sample of the pegmatite in (c), composed mainly of K-feldspars and quartz (Kfs-Qz), with minor amounts of garnet $(\mathrm{Gt})$ and biotite $(\mathrm{Bt})$. 
uraninite, along with other minerals such as muscovite, phlogopite, feldspars and quartz (translucent, milky and smoked) [8]. Chemical analyzes show that the average concentrations of radioactive elements in the Vertientes pegmatite (23 ppm of Th and $73 \mathrm{ppm}$ of $\mathrm{U}$ ), are lower than those found in the Poñén pegmatite (489 ppm of Th and $2096 \mathrm{ppm}$ of U); however, these are higher than the global mean values for intrusive rocks and the granitic basement, that is to say, where they are located (12 ppm of Th and $3 \mathrm{ppm}$ of U; [10]). Regarding the rare earth elements, the average concentration in the Vertientes pegmatite (610 ppm) is higher than the Poñén pegmatite (321 ppm) [8] [10].

\section{Methodology}

Rock fragments were collected according to representative volumes of mineral aggregates exposed along to the outcrops of the Vertientes pegmatite, considering high, medium and low radioactivity, measured with a portable gamma-ray integration spectrometer (GIS-5). These fragments were milled, homogenized and divided into two composite subsamples for mineralogical analysis. One subsample was pulverized at -200 mesh and then used for X-ray diffraction analysis (Rigaku, RAD-2, with horizontal goniometer). The other one, pulverized at -80 mesh, was used to prepare polished-transparent sections and study them by optical microcopy (Zeiss Universal) and electron probe micro-analyzer (EPMA; JEOL JXA8600M). With this subsample, qualitative (EDS: energy dispersive system) analysis were obtained. Additionally, through optical microscopy and EPMA, a polished-transparent section representative of the granitic rocks (without milling) found near to the Vertientes pegmatite was studied in order to determine REE minerals.

\section{Results}

\subsection{Mineralogy of the Vertientes Pegmatite}

The Vertientes pegmatite is characterized mainly by coarse crystals of orthoclase, microcline, anorthoclase, albite, quartz and minor amounts of muscovite, biotite and almandine garnet. The feldspars are visible in slightly altered outcrops, but generally are strongly altered to clays, which mostly correspond to illite. Part of these nonmetallic minerals are mixed with uranium and thorium minerals, whose radioactivity had been previously registered in the field by a gamma-ray integration spectrometer (values between 2000 and 220 accounts per second). X-ray diffraction analysis showed uranium minerals such as coffinite $\left(\mathrm{USiO}_{4}\right)$ and metaschoepite $\left(\mathrm{UO}_{3} \cdot 2 \mathrm{H}_{2} \mathrm{O}\right)$ (Figure 5). The coffinite is a primary mineral and the metaschoepite is a secondary mineral derived from alteration of primary radioactive minerals [34].

The optical microscopy and EPMA (EDS data; Table 1) analysis revealed the presence of xenotime, thorite, monazite and thorium silicate \pm uranium, as described below:

Xenotime. Frequently occurs in particles between 3 and 20 microns long, usually in contact with monazite and minorly along to thorium silicate (thorite) 


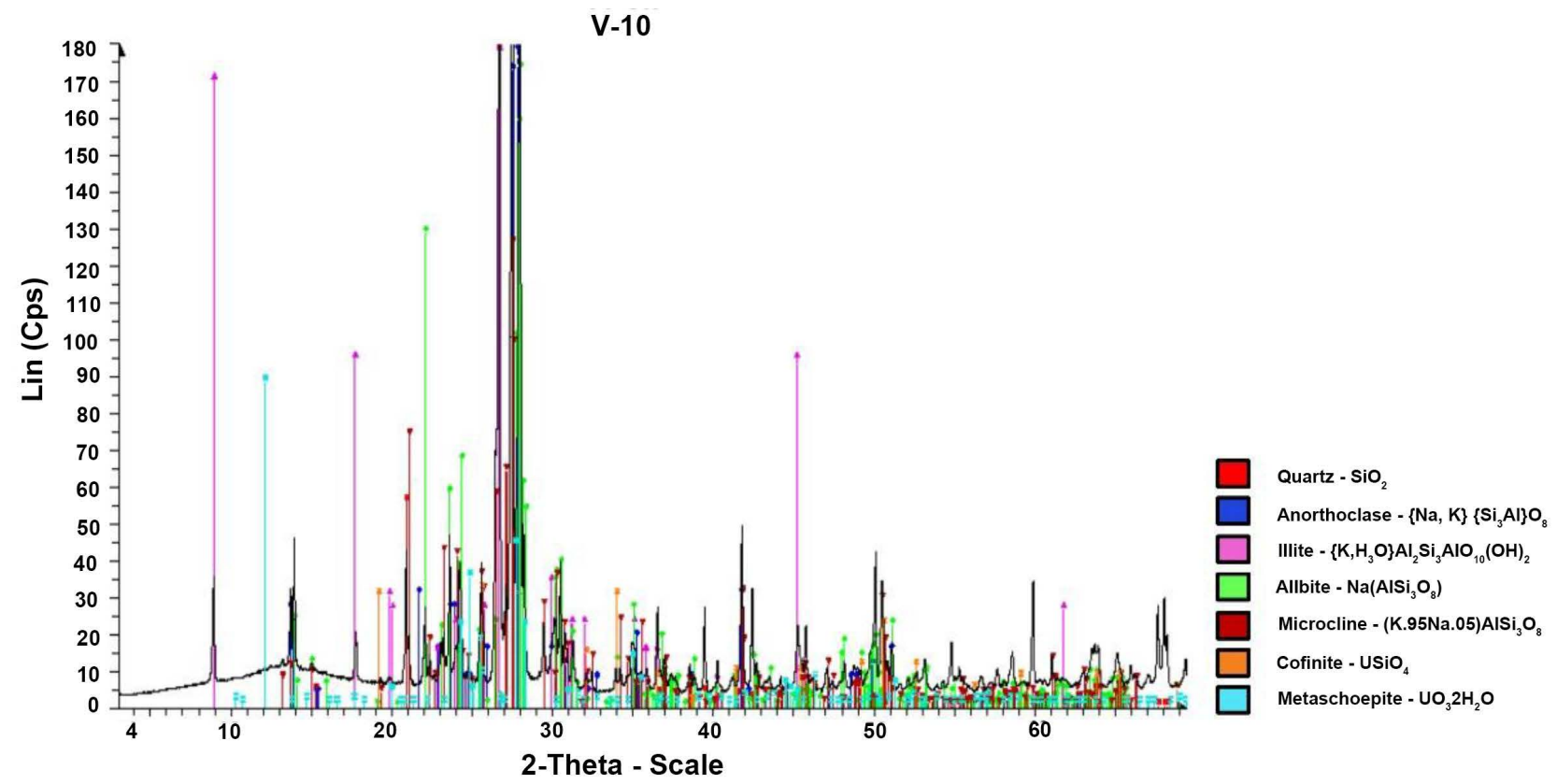

Figure 5. Difractogram showing the presence of microcline, anorthoclase, albite, quartz, illite, coffinite and metaschoepite. Sample V-10, Vertientes pegmatite. L in (Cps): Log intensity (Counts per second).

Table 1. Elements (wt\% normalized to $100.00 \%$ ) determined by EPMA for the Vertientes pegmatite.

\begin{tabular}{|c|c|c|c|c|c|c|c|c|c|c|c|c|c|c|c|c|c|c|c|c|c|c|c|}
\hline Point & $\mathrm{O}$ & $\mathrm{F}$ & $\mathrm{Si}$ & $\mathrm{P}$ & $\mathrm{Ca}$ & $S$ & $\mathrm{Y}$ & $\mathrm{La}$ & $\mathrm{Ce}$ & $\mathrm{Nd}$ & $\mathrm{Pm}$ & $\mathrm{Sm}$ & $\mathrm{Eu}$ & $\mathrm{Gd}$ & $\mathrm{Tb}$ & Dy & Ho & Er & $\mathrm{Tm}$ & $\mathrm{Yb}$ & $\mathrm{Pb}$ & $\mathrm{Th}$ & $\mathrm{U}$ \\
\hline 1 & 38.29 & & & 19.28 & & 0.97 & & 14.23 & 27.23 & & & & & & & & & & & & & & \\
\hline 2 & 21.88 & & 0.51 & 15.47 & & & & 7.75 & 25.64 & 16.36 & & 4.87 & & & & & & & & & & 7.52 & \\
\hline $3 \mathrm{~A}$ & 12.03 & & 6.39 & 0.72 & 0.76 & & & & & & & & & & & & & & & & & 71.52 & 8.58 \\
\hline $3 \mathrm{~B}$ & 24.42 & 0.92 & 8.96 & & & & & & & & & & & & & & & & & & 1.55 & 46.79 & 17.36 \\
\hline $3 \mathrm{C}$ & 21.10 & & & 14.62 & & & & 9.47 & 28.71 & 17.40 & & 6.30 & & & & & & & & & & 2.40 & \\
\hline 4 & 21.47 & & & 14.21 & & & & 9.62 & 29.29 & 16.54 & & 4.86 & & & & & & & & & & 4.01 & \\
\hline $5 \mathrm{~A}$ & 20.82 & & & 14.52 & & & & 11.52 & 30.81 & 16.14 & & 4.54 & & & & & & & & & & 1.65 & \\
\hline $5 \mathrm{~B}$ & 13.24 & & 5.39 & 1.46 & & & & & & & & & & & & & & & & & & 79.91 & \\
\hline $6 \mathrm{~A}$ & 20.17 & & 0.35 & 13.20 & & & & 12.90 & 28.15 & 15.31 & & 6.06 & & & & & & & & & & 3.86 & \\
\hline $6 \mathrm{~B}$ & 13.85 & 0.16 & 8.55 & 0.95 & 1.18 & & & & 1.26 & 1.30 & & & & & & & & & & & 1.27 & 66.96 & 4.52 \\
\hline $6 \mathrm{C}$ & 22.73 & & 0.75 & 15.34 & & & 34.93 & & 1.24 & 0.91 & 0.35 & 0.89 & 0.76 & 5.89 & 3.17 & 10.98 & & & & & & 2.06 & \\
\hline
\end{tabular}

(Figure 6(a)). Xenotime is commonly considered as an yttrium phosphate $\left(\mathrm{YPO}_{4}\right.$; [35] or (Y, REE)PO4; [36]). Analyzes by EPMA show that the phosphorus and yttrium are the major components; O $(22.7 \%-23.7 \%), \mathrm{P}(15.3 \%-$ $15.4 \%)$ and $\mathrm{Y}(34.9 \%-37.1 \%)$ (5C and 6C; Table 1$)$, followed by the heavy rare earth elements (HREE); Dy (8.3\% - 11\%), Gd (4.4\% - 5.9\%), Tb (1.4\% - 3.2\%), and the radioactive element Th $(1.6 \%-2.1 \%)$. Furthermore, other HREE were detected, which correspond to $\mathrm{Er}$ (2.94\%), Ho (1.42\%), Yb (1.23\%) and Tm 

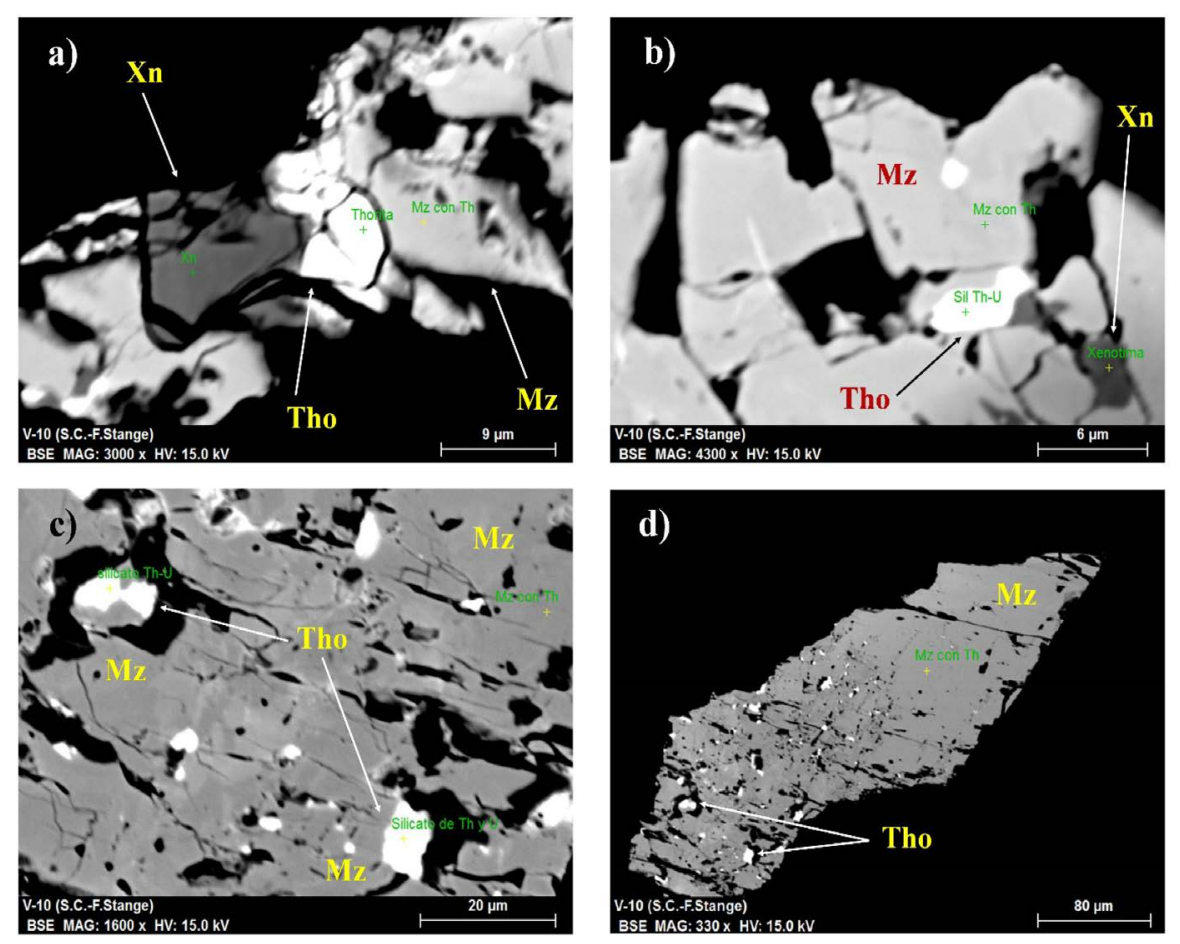

Figure 6. EPMA-backscattered electron (EPMA-BSE) images of REE and Th-U bearing minerals of the Vertientes pegmatite. (a) Xenotime (Xn; $5 \mathrm{C}$ ), thorite (Tho; $5 \mathrm{~B}$ ) and monazite $(\mathrm{Mz})$ with Th $(5 \mathrm{~A})$. (b) Xenotime inclusions (Xn; 6c) and $\mathrm{Th} \pm \mathrm{U}$ silicate (Tho; 6B) whithin monazite $(\mathrm{Mz})$. (c) Th $\pm \mathrm{U}$ silicate inclusions (Tho; $3 \mathrm{~A}$ and $3 \mathrm{~B}$ ) in monazite $(\mathrm{Mz})$. (d) Coarse monazite crystal $(\mathrm{Mz})$ showing small disseminated inclusions of $\mathrm{Th} \pm \mathrm{U}$ silicate (Tho). Measured points are in the Table 1.

(0.7\%), besides minor contents of light rare earth elements (LREE) such as Ce, $\mathrm{Nd}, \mathrm{Pm}, \mathrm{Sm}$ and $\mathrm{Eu}(1.24 \%-0.4 \%)$ (5C and 6C; Table 1).

Thorite. This mineral occurs in particles of 2 to 10 microns, normally in contact with xenotime and monazite, or occluded in monazite. Compositionally the thorite is defined as $\mathrm{Th}\left(\mathrm{SiO}_{4}\right)$ [37], as well as ( $\left.\mathrm{Th}, \mathrm{U}\right) \mathrm{SiO}_{4}$ [38]. In this research, analyzes by EPMA tend to reflect both formulas. In the first case, the minerals found contain $\mathrm{O}(13.2 \%), \mathrm{Si}(5.4 \%)$ and $\mathrm{Th}$ (79.9\%) as main elements, and very low $\mathrm{P}(1.46 \%)$ (5B; Table 1), probably due to contamination of $\mathrm{P}$ from adjacent contact with rare earth phosphates, xenotime and monazite (Figure 6(a)). In the second case, $\mathrm{O}(13.9 \%), \mathrm{Si}(8.6 \%)$, Th (67\%) and $\mathrm{U}(4.5 \%)$ were detected as main elements, along with low contents of $\mathrm{Pb}(1.3 \%), \mathrm{Ca}(1.2 \%), \mathrm{P}(1 \%), \mathrm{F}(0.2 \%)$ and REE such as $\mathrm{Nd}(1.3 \%)$ and $\mathrm{Ce}(1.26 \%)$ (6B; Table 1, Figure 6(b)).

Other inclusions of thorite in monazite on two other analyzed points, with grains between 1 and 10 microns, are determined (Figure 6(c)). These show contents of $\mathrm{O}$ (12\% and $24.4 \%), \mathrm{Si}(6.4 \%$ and $9 \%)$, Th (71.5\% and $46.8 \%), \mathrm{U}$ (8.6\% and $17.4 \%)$ and scarce contents of $\mathrm{Pb}(1.6 \%), \mathrm{F}, \mathrm{P}$ and $\mathrm{Ca}(0.7 \%-0.9 \%)$ (3A and 3B; Table 1).

Monazite. It usually occurs in large crystals which can reach up to 400 microns long, often with small inclusions corresponding to thorite \pm uranium (Figure 6(b), Figure 6(c) and Figure 6(d)) and lesser amounts of xenotime (Figure 
6(c)). The monazite occurs commonly in simple contact with other nonmetallic minerals, such as quartz crystals (Figure 7(a)) and K-feldspar (Figure 7(b)) which correspond to microcline (Figure 5), according to X-ray diffraction analysis.

From all points analyzed with electron microprobe, the minerals detected were mainly monazite, composed exclusively of LREE. Although xenotime was detected in a smaller proportion, it mostly displays HREE with some LREE, as the average ele-mental content (Figure 8; Table 1) for each mineral indicates.

Monazite has been defined as a phosphate of cerium, lanthanum, neodymium and thorium (Ce, $\mathrm{La}, \mathrm{Nd}, \mathrm{Th}) \mathrm{PO}_{4}$ [39]. Some authors argue that, in fact, monazite is a phosphate of cerium, lanthanum and dysprosium (Ce, La, Dy) $\mathrm{PO}_{4}$ [40]. The data collected in this research resembles the first definition more, as Th was identified in five of the six points and the second definition, only in one point (1; Table 1). In this point, the main components that characterize this mineral are: O (38.3\%), P (19.3\%), Ce (27.2\%) and La (14.2\%), in addition to minor contents of $\mathrm{S}(1 \%)$. For the other points where monazite with Th $(7.5 \%-1.7 \%)$ was measured, the principal elements were: O $(20.2 \%-21.9 \%), \mathrm{P}(15.5 \%-13.2 \%)$, the LREE: Ce (30.8\% - 25.6\%), Nd (17.4\% - 15.3\%), La (11.5\% - 7.8\%), Sm (6.3\% - $4.5 \%)$, and minor contents of $\mathrm{Si}(0.5 \%-0.4 \%)$ detected occasionally $(2,3 \mathrm{C}, 4$, 5A, 6A; Table 1).

\subsection{Mineralogy of the Granitic Rocks from South Coastal Batholith}

From observations of a selected thin section in reflected light, corresponding to a biotite granite (Figure 9(a)), groups of small minerals with higher reflectivity percentage than the other minerals (Figure 9(b); accessory minerals: $\sim 0.5 \%$ ) were detected, especially pyrite (near to $50 \%$ ), followed by monazite, whose reflectivity is between $8 \%$ and $15 \%$, and with yellowish-brown inner reflects [39] [41].

These minerals were examined by means of EPMA, showing a stronger backscattered electron (BSE) signal (brighter) than the rock forming minerals
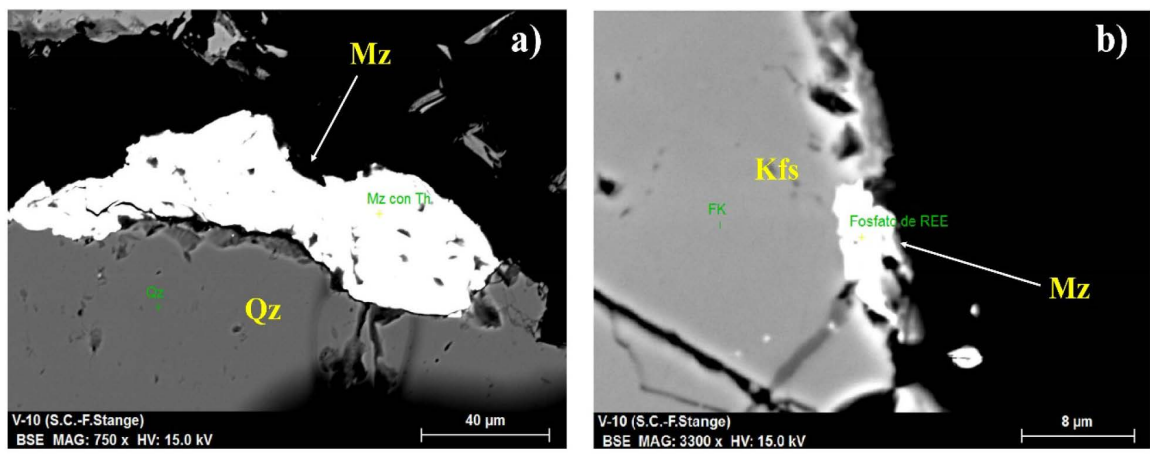

Figure 7. EPMA-backscattered electron (EPMA-BSE) images showing monazite $(\mathrm{Mz})$ associated with other nonmetallic minerals. (a) Monazite crystal (Mz) with Th contents, in contact with quartz $(\mathrm{Qz})$. (b) Monazite crystal $(\mathrm{Mz})$ in contact with $\mathrm{K}$-feldspar (Kfs). 


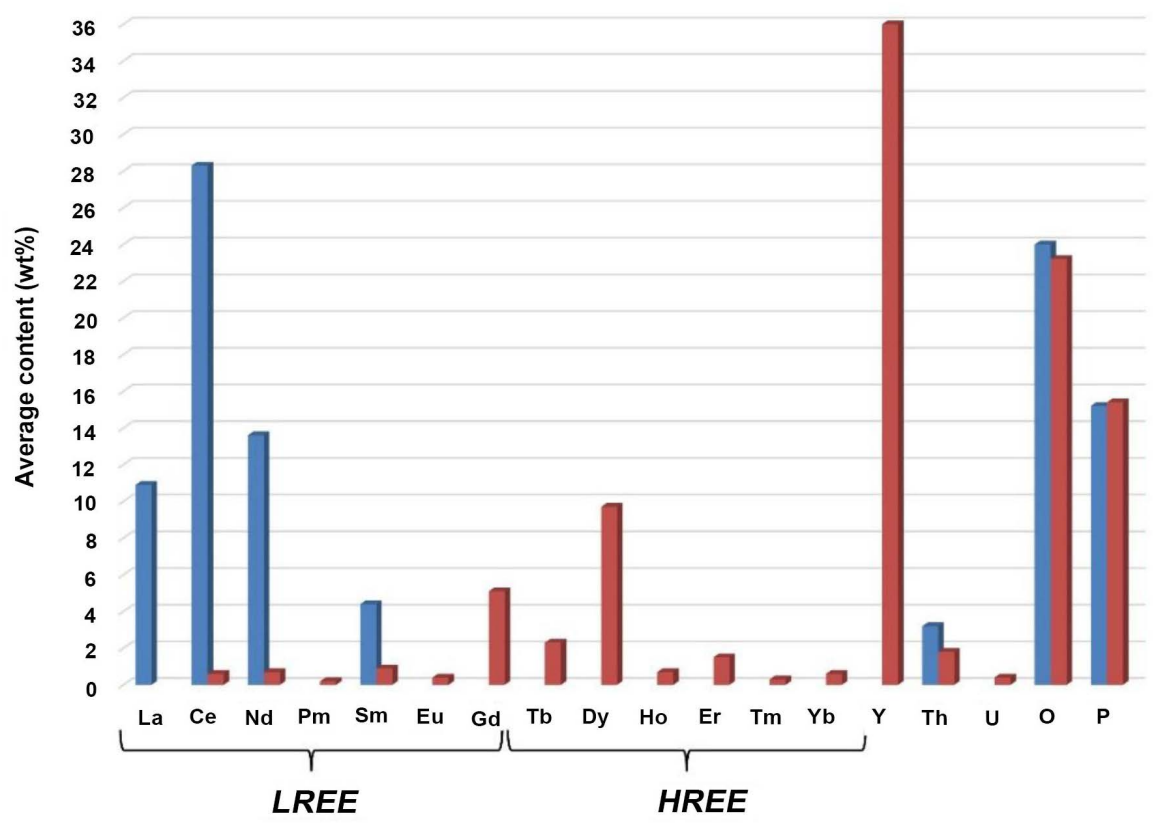

Figure 8. Average content of LREE, HREE, Y, Th, U, O and P in phosphates of the Vertientes pegmatite. Blue: monazite, red: xenotime.
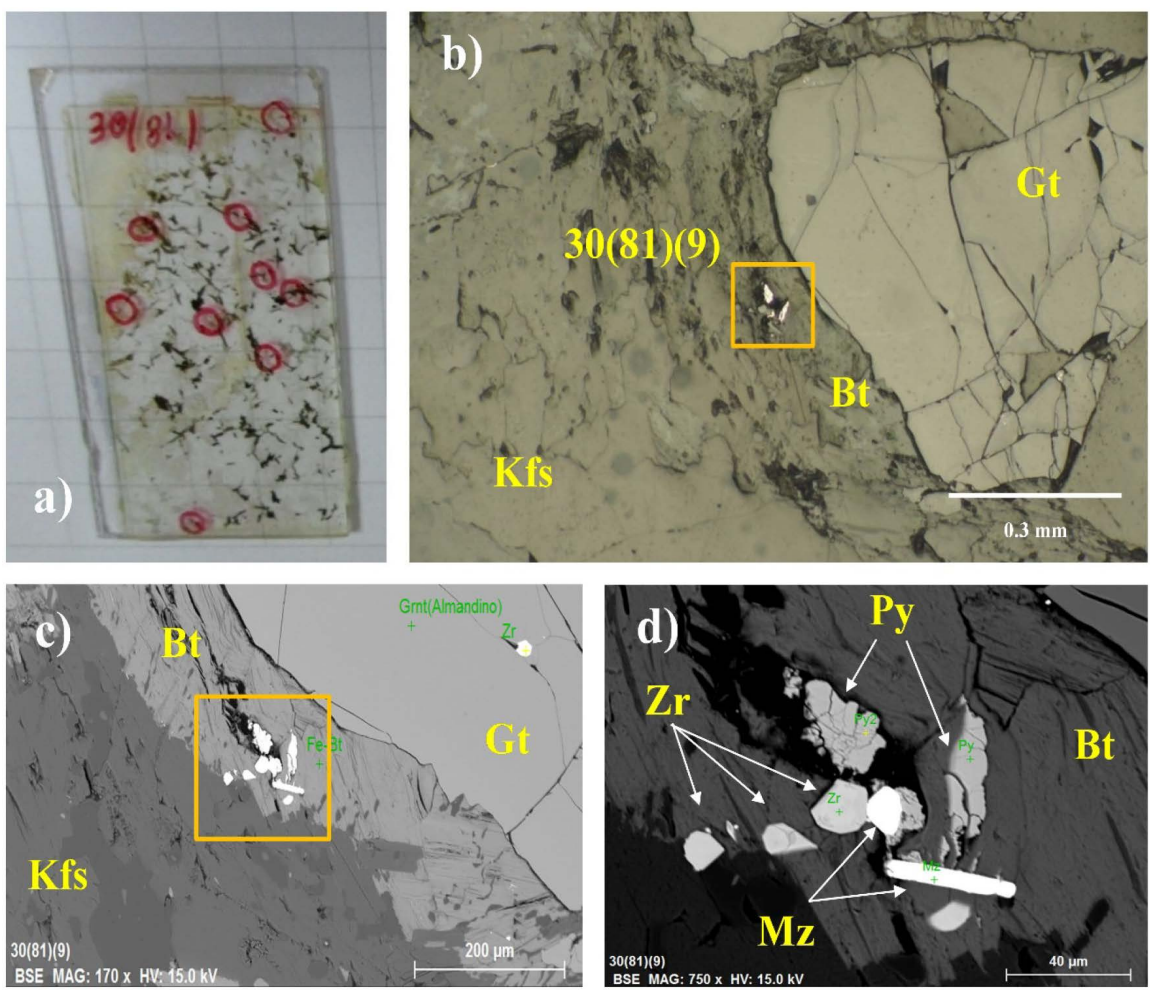

Figure 9. Accessory minerals in biotite granite from South Coastal Batholith. (a) Thin section of sample 30 (81), where 9 points with grains of high reflectivity in reflected light were identified. (b) Point 30 (81) (9) showing K-feldspar (Kfs), biotite (Bt), garnet (Gt) and a group of minerals with high reflectivity (orange box). (c) BSE image of the area near orange box in (b). (d) BSE image of the area where the most reflective minerals are found; pyrite $(\mathrm{Py})$, zircon $(\mathrm{Zr})$ and monazite $(\mathrm{Mz})$, included within biotite $(\mathrm{Bt})$. (b) obtained under optical microscope; (c) and (d) obtained by EPMA. 
(Figure 9(c)). The accessory minerals observed were pyrite, zircon and monazite (Figure 9(d)).

The main minerals recognized by optical microscopy and EPMA are quartz, K-feldspar, plagioclase and biotite (Figure 10(a)). Different points of the thin section show monazite grains. This mineral usually occurs as fracturated subhedral crystals (Figure 10(b) and Figure 10(c)), with sizes varying between 40 and $70 \mu \mathrm{m}$, associated to all rock-forming minerals. In addition, other accessory minerals such as muscovite and allanite were detected. The latter is a mineral from the epidote group that contains rare earth elements

(Ca-Ce) $\left(\mathrm{Al}_{2} \mathrm{Fe}_{2}^{+}\right)\left(\mathrm{Si}_{2} \mathrm{O}_{7}\right)\left(\mathrm{SiO}_{4}\right) \mathrm{O}(\mathrm{OH})$, where $\mathrm{Ce}$ can be replaced by $\mathrm{La}$, Nd and $\mathrm{Y}$ [42]. This is observed within quartz, as small subhedral-anhedral grains $(<10$ $\mu \mathrm{m})$ (Figure 10(d)).

The elements in monazites from Figure 10(b) and Figure 10(c) were determined by electron microprobe (Mz1 and Mz2, respectively; Table 2). These show only LREE, dominated by Ce, $\mathrm{Nd}$ and La, followed by $\operatorname{Pr}$ (5.49\% for Mz1 and 3.59\% for Mz2), element that is not present in minerals from the Vertientes pegmatite, minor contents of Sm, Pm (only Mz1), Gd and Ca. Both measurements show that these monazites have contents of Th $(2.05 \%$ for $\mathrm{Mz} 1$ and $3.28 \%$ for Mz2).

In addition, some high count single point EDS spectra show the presence of allanite with rare earth elements, particularly the LREE La, Ce, Nd, Sm and Gd
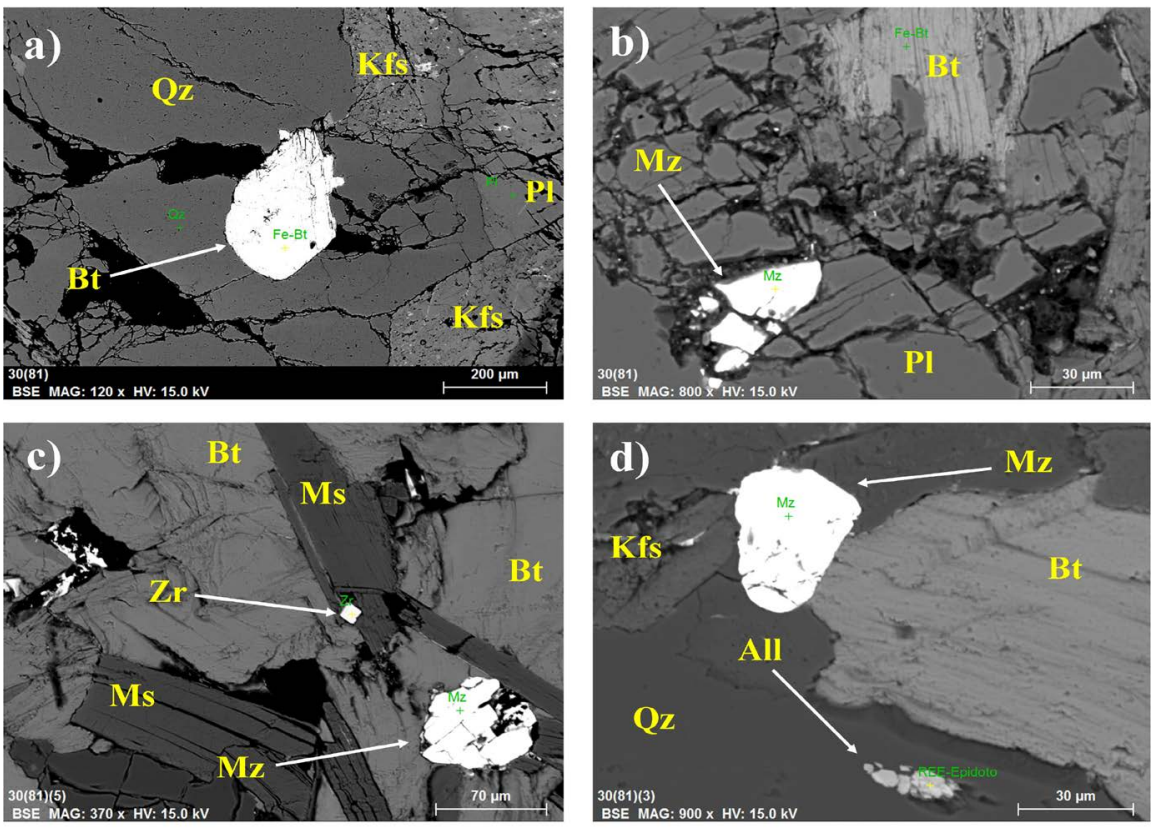

Figure 10. EPMA-backscattered electron (EPMA-BSE) images showing the mineralogy of biotite granite from South Coastal Batholith. (a) Rock forming minerals: quartz (Qz), K-feldspar (Kfs), plagioclase ( $\mathrm{Pl})$ and biotite (Bt). (b) Monazite (Mz) within plagioclase (Pl). (c) Monazite crystal (Mz) in contact with biotite (Bt) and muscovite (Ms). (d) Monazite crystal $(\mathrm{Mz})$ in contact with $\mathrm{K}$-feldspar $(\mathrm{Kfs})$, quartz $(\mathrm{Qz})$ and biotite $(\mathrm{Bt})$, and allanite (All) within quartz. 
Table 2. Elements (wt\% normalized to 100.00\%) determined by EPMA for monazites from South Coastal Batholith.

\begin{tabular}{cccccccccccc}
\hline Point & $\mathrm{O}$ & $\mathrm{P}$ & $\mathrm{Ca}$ & $\mathrm{La}$ & $\mathrm{Ce}$ & $\mathrm{Pr}$ & $\mathrm{Nd}$ & $\mathrm{Pm}$ & $\mathrm{Sm}$ & $\mathrm{Gd}$ & $\mathrm{Th}$ \\
\hline $\mathrm{Mz} 1$ & 4.21 & 8.05 & 0.20 & 12.26 & 39.35 & 5.49 & 20.05 & 2.58 & 4.06 & 1.80 & 2.05 \\
$\mathrm{Mz2}$ & 20.12 & 14.16 & 0.38 & 9.95 & 29.90 & 3.59 & 14.15 & - & 3.01 & 1.46 & 3.28 \\
\hline
\end{tabular}

(Figure 11), where Ce is the predominant element, along with $\mathrm{La}$ and $\mathrm{Nd}$ in a lesser concentration.

\section{Discussion}

The development of a rare earth elements resource with economic potential requires that these elements are concentrated significantly above the average bulk continental crust ( 125 ppm; [43]) [1]. Enrichment of the REE may occur through primary processes such as magmatic processes and hydrothermal fluid mobilization and precipitation, or through secondary processes that move REE minerals from where they originally formed, such as weathering and sedimentary concentration [44]. These concentrations occur primarily in the following geologic environments: carbonatites and alkaline igneous systems (primary deposits), ion-absorption clays and monazite-xenotime-bearing placers (secondary deposits) [1] [44] [45] [46] [47].

Primary REE concentrations can also be formed in a range of other geological settings, often associated with granitic rocks and pegmatites or with hydrothermal systems [1] [47]. In the case of the pegmatites and rocks of the South Coastal Batholith, these are the product of a voluminous calc-alkaline magmatism, which is an unfavorable setting to generate REE enrichment [1]; and therefore, probably not exploitable. However, if these have been weathered or eroded, they may produce secondary deposits, as it is the case of the El Cabrito project belonging to BioLantanidos Mining in the BioBío region (Figure 12), which can be considered as a form of ion-absorption clay deposit. In this type of deposits, thick clay accumulations or regolith over granite bedrocks host low concentrations of REE ( $\sim 0.04 \%$ to $0.25 \%$ total REE oxides in south China deposits; [45] [46] [47]).

Other type of REE deposit can be found in some modern and ancient beach deposits [48], where the monazite can be recovered as a byproduct during the extraction of the targeted heavy minerals, ilmenite $\left(\mathrm{FeTiO}_{3}\right)$, rutile $\left(\mathrm{TiO}_{2}\right)$, and zircon $\left(\mathrm{ZrSiO}_{4}\right)$ [45]. Ilmenite and rutile are mechanically separated from sand-silt deposits and the monazite can be recovered simultaneously. For example; monazite is recovered as a mineral byproduct from beach sands along the southern coasts of India, where it is sought as a source of LREE and Th [49]; the placers of the Brazilian coast mined mainly for monazite, and also for titanium minerals (ilmenite, rutile) and zircon in different types of deposits such as modern beaches, paleobeaches and dunes [48]. Xenotime has been recovered as a source of yttrium and other REE as a byproduct of mining tin placers [46]. In 


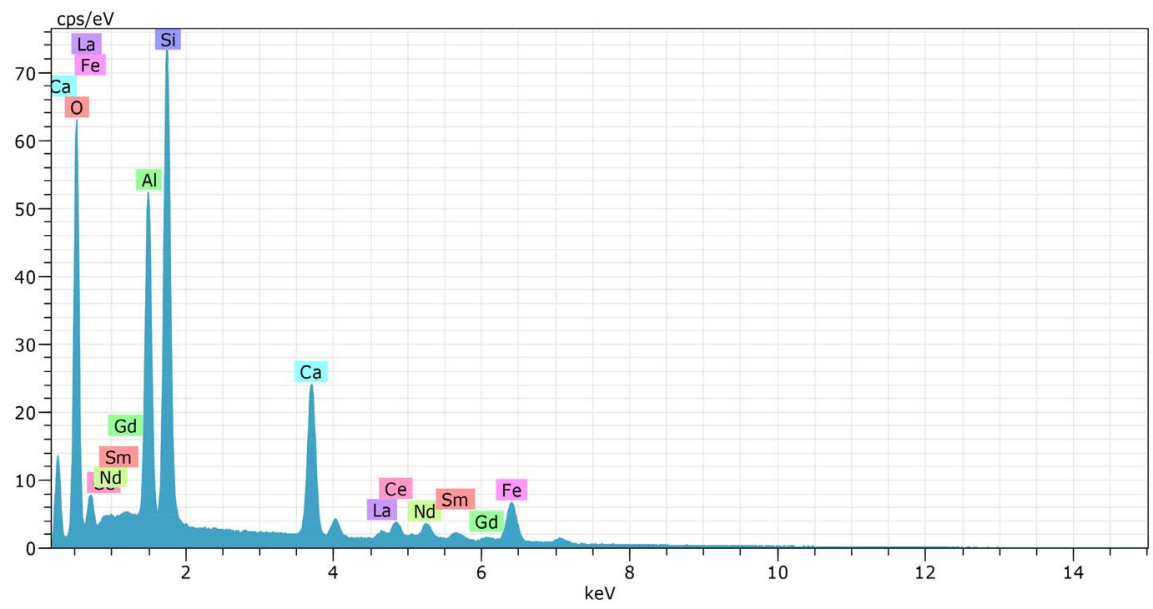

Figure 11. High count single point EDS spectrum of allanite obtained by EPMA, indicating the presence of REE elements. cps: counts per second; keV: kiloelectron volt.

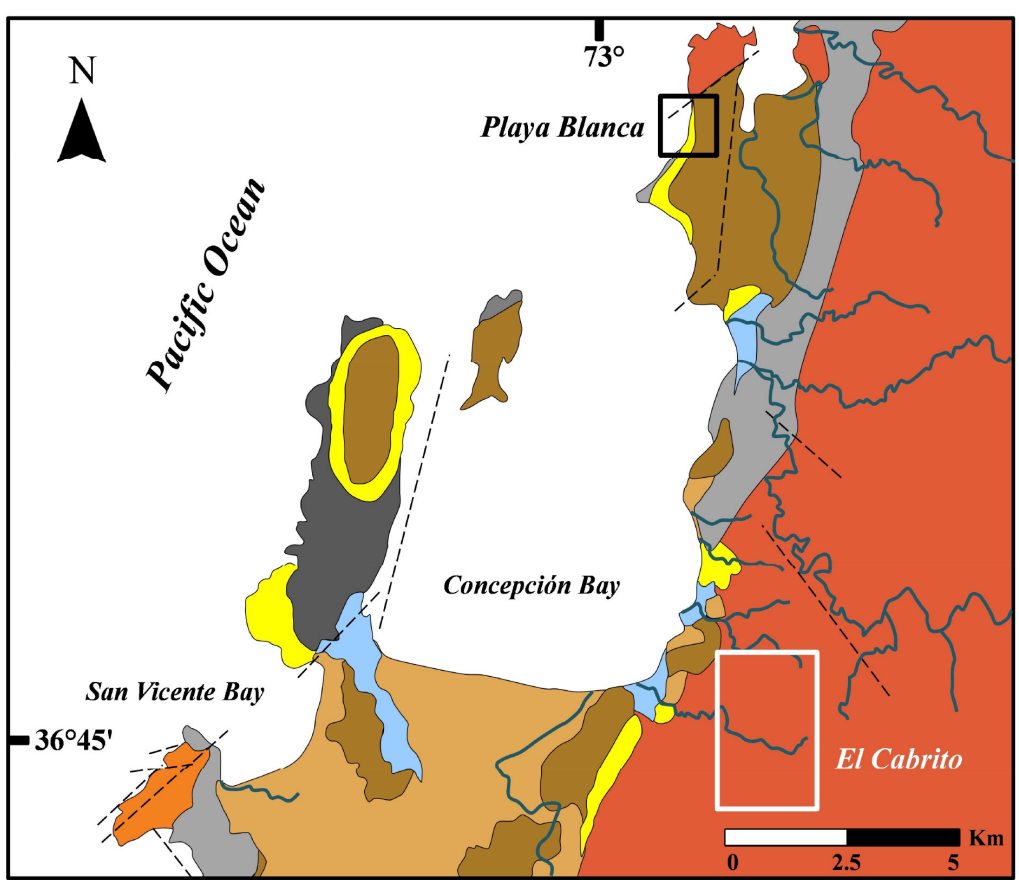

\section{Legend}

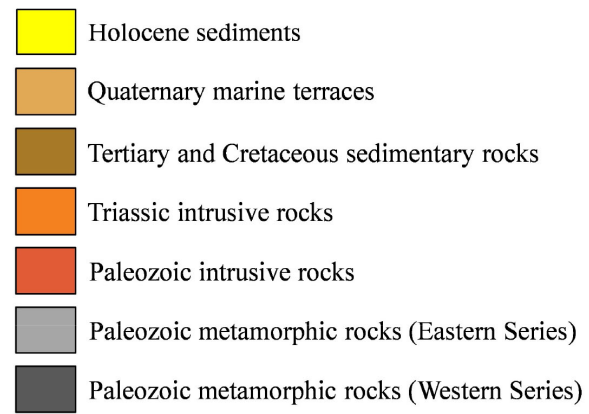

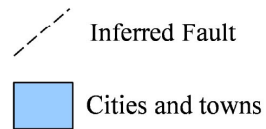

?h Rivers

Figure 12. Geological setting of the Concepción area (adapted from [51]). Black box: location of Fe-Ti placer of Playa Blanca [51]. White box: location of El Cabrito project [7]. 
the case of the Malaysian deposits, xenotime and monazite are found along with other heavy minerals (e.g., ilmenite, rutile, zircon, cassiterite and wolframite; [50]), mainly in alluvial placers but the host streams and rivers move bedload carrying heavy minerals farther downstream and ultimately reach the coastal plain [46].

In the coastal area of the BioBío region, Collao et al. (1982) [51] studied the Fe-Ti beach placer of Playa Blanca, located $30 \mathrm{~km}$ NNW of Concepción (Figure 12). The deposit has a length of $1500 \mathrm{~m}$ and width of $30-50 \mathrm{~m}$, abruptly limited by Cretacic-Cenozoic sedimentary rocks and granitic rocks of the Paleozoic Batholith. The mineralization consist of three, $60-70 \mathrm{~cm}$ thick, terraces composed of unconsolidated horizons of black very fine grained sands, from 2 to $6 \mathrm{~cm}$ thick. Fe and Ti minerals (monomineral grains: 15.4\%) are: titanomagnetite (9.8\%), magnetite $(2.5 \%)$, ilmenite $(1.4 \%)$, hematite $(0.9 \%)$, sphene $(0.7 \%)$ and rutile $(0.1 \%)$. The mixed grains (4\%) are mainly exsolutions composed of: magnetite-hematite (1.9\%), hematite-ilmenite (1.2\%), magnetite-ilmenite (0.6\%) and sphene-nonmetallic $(0.3 \%)$. Nonmetallic grains represent a high percentage $(80.6 \%)$, but they were not studied. Furthermore, two chemical analyzes were made, indicating concentrations of $11 \%$ and $20 \%$ for $\mathrm{Fe}$, and of $2.2 \%$ and $4.4 \%$ for Ti.

The type of heavy minerals that can be found within the heavy mineral sands depends directly on the type of bedrock sources. Common minerals found in heavy mineral sands are ilmenite and rutile, as well as garnets, staurolite, monazite, xenotime, and kyanite or sillimanite, which are typical of intermediate to high grade (amphibolite to granulite) metamorphic facies [46]. Igneous rocks are typically considered subordinate sources of heavy minerals in comparison to metamorphic rocks [52]. These type of rocks contain ilmenite, rutile, garnets, monazite and zircon, which are important sources for heavy mineral sand deposits (e.g., beach sands of southern India; [53]). Plutonic rocks contribute the most detritus to a coastal basin simply because sizeable plutons have the capacity to supply the largest volume of detritus, especially when this is deeply weathered [46]. Sedimentary rocks in coastal regions can contain enrichments in heavy minerals derived from erosion of older igneous and metamorphic rocks; and therefore, these can be intermediate hosts of heavy minerals that are later deposited in beach sands [46].

In the BioBío region, heavy minerals have been identified mainly within metamorphic and intrusive rocks, and slightly in sedimentary rocks. The Oriental Series of the Metamorphic Basement has ilmenite, rutile, sphene, garnets, staurolite and sillimanite [31] [54] [55], whereas the Western Series has mainly magnetite [12]. The South Coastal Batholith has several heavy minerals such as ilmenite, zircon, epidote ( \pm allanite), rutile, sphene, garnets and amphibole (e.g., [12] [20] [21] [29] [56]), although in most cases many accessory minerals have only been classified as opaque. In this work, the presence of REE minerals is represented by monazite and allanite in granitic rocks, as well as monazite and xenotime in the Vertientes pegmatite. Additionally, REE minerals have been de- 
tected in the Poñén pegmatite (monazite; [21]) and Coyanmahuida pegmatite (xenotime; [57]). Therefore, it is possible that these ocurrences can feed the heavy mineral sand deposits, due to its proximity to the coast. The ocurrences of heavy minerals within sedimentary rocks have been scarcely studied. The coastal area of Lebu, located $200 \mathrm{~km}$ south of Playa Blanca, displays sandstone blocks with high Fe-Ti concentrations along the beach [51]. These blocks (up to $2 \mathrm{~m}$ long) are situated immediately next to a cliff, tectonically uplifted, composed by marine Paleocene-Eocene sandstones at its lower part, followed by continental Paleocene-Eocene sandstones at the upper part. Here, marine sandstones are probably the source of the Fe-Ti blocks, because they show a high content of heavy minerals, mostly ilmenite (19.3\%) with lesser amounts of titanomagnetite (1.6\%) and rutile $(0.3 \%)$.

Economically productive heavy mineral sands are found commonly in the passive margins; however, relatively recent studies have interpreted direct links of tectonically active margins with the formation of these deposits [46], as terrace or strandline systems [58] [59]. An example is the Cenozoic Eucla basin of southern Australia, where differential vertical movements and tilting since the Eocene to Quaternary have promoted the sedimentation and rework of heavy minerals for at least 50 million years [59] [60]. Faulting also may enhance sedimentation or control the distribution of heavy mineral deposition in a coastal basin, as is the case in the Murray Basin (Australia), with more than $100 \mathrm{Pli}$ ocene coastal sand deposits [58] [61].

The stable tectonic setting during the Pliocene-Quaternary, along with uplift and marine regression in the coastal area of south-central Chile [62], have allowed the formation of terraces in the Playa Blanca deposit. Additionally, the sedimentary sequence of the Lebu beach constitute evidence of the transgression and regression episodes within a forearc basin over a continental shelf with epeirogenic movements from Paleocene to Quaternary (Figure 3; [26]). This is a favorable geological setting to generate heavy mineral sand deposits. Then, this type of deposits could be explored along the coastline, in order to search REE minerals due to the ocurrences found inland ( $\sim 30 \mathrm{~km}$ from the coast), within the South Coastal Batholith and their associated pegmatites.

\section{Conclusions}

Through optical microscopy, X-ray diffraction and EPMA analysis, it was possible to detect the presence of REE minerals within the Paleozoic Batholith. The REE minerals found in the Vertientes pegmatite were monazite and xenotime. Monazite only contains LREE and often, small inclusions of thorite and Th-U silicate (thorite $\pm U$ ), whereas the xenotime has mainly HREE with minor contents of LREE. In addition, this pegmatite has uranium minerals (coffinite and metaschoepite), along with microcline, anorthoclase, albite, quartz and illite. REE minerals have also been detected in rocks from the South Coastal Batholith (biotite granite), corresponding to monazite with LREE and Th, and allanite whit LREE. 
Both tectonic and geologic setting facilitate the generation of heavy mineral sand deposits in the coastal area of the BioBío region in south-central Chile, as the Playa Blanca beach placer. These deposits host some economic minerals such as ilmenite, magnetite and rutile, but they can also be explored for REE minerals, due to evidence of monazite, xenotime and allanite found within the Paleozoic Batholith and their associated pegmatites ( $30 \mathrm{~km}$ from the coast).

\section{Acknowledgements}

The results of this work are part of the DIUC 20099925036-1 project, financially suported by Universidad de Concepción. We are grateful to the group of experts at the Ciencias de la Tierra Department and GEA Institute (Universidad de Concepción) for their collaboration in field and laboratory work.

\section{Conflicts of Interest}

The authors declare no conflicts of interest regarding the publication of this paper.

\section{References}

[1] Goodenough, K.M., Schilling, J., Jonsson, E., Kalvig, P., Charles, N., Tuduri, J., Deady, E.A., Sadeghi, M., Schiellerup, H., Müller, A., Bertrand, G., Arvanitidis, N., Eliopoulos, D.G., Shaw, R.A., Thrane, K. and Keulen, N. (2016) Europe's Rare Earth Element Resource Potential: An Overview of REE Metallogenetic Provinces and Their Geodynamic Setting. Ore Geology Reviews, 72, 838-856.

https://doi.org/10.1016/j.oregeorev.2015.09.019

[2] Comisión Chilena del Cobre (Cochilco) (2016) Situación actual del mercado de tierras raras y su potencial en Chile. Santiago, $55 \mathrm{p}$.

[3] Guyonnet, D., Planchon, M., Rollat, A., Escalon, V., Tuduri, J., Charles, N., Vaxelaire, S., Dubois, D. and Fargier, H. (2015) Material Flow Analysis Applied to Rare Earth Elements in Europe. Journal of Cleaner Production, 107, 215-228. https://doi.org/10.1016/j.jclepro.2015.04.123

[4] Damascena, K.R., dos Santos Amaral, R., dos Santos Júnior, J.A., Genzini, F.A., da Silva, A.A. and Menezes, R.S.C. (2015) Rare-Earth Elements in Uranium Deposits in the Municipality of Pedra, Pernambuco, Brazil. Journal of Radioanalytical and Nuclear Chemistry, 304, 1053-1058. https://doi.org/10.1007/s10967-015-3934-7

[5] Gambogi, J. (2019) Mineral Commodity Summaries 2019. U.S. Geological Survey, 132-133. https://doi.org/10.3133/70180197

[6] Gambogi, J. (2018) Mineral Commodity Summaries 2018. U.S. Geological Survey, 132-133. https://doi.org/10.3133/70194932

[7] REE UNO SpA (2016) Proyecto Minero el Cabrito. Declaración de Impacto Ambiental, Minera BioLantánidos.

[8] Collao, S., González, L. and Flores, G. (2009) Mineralización de Uranio en Afloramiento Pegmatítico, VIII Región del Bio Bío, Chile. XII Congreso Geológico Chileno, Santiago, $4 \mathrm{p}$.

[9] Collao S., Correa, K., González, L. and Velásquez, R. (2012) Inclusiones fluidas en las pegmatitas uraniníferas de Poñén, Región del Biobío Chile. XIII Congreso Geológico Chileno, Antofagasta, 3 p. 
[10] Collao, S., González, L., Hernández, L. and Jil, D. (2015) Mineralogía y Anomalías Geoquímicas de U, Th y Tierras Raras, en Pegmatita de Coyanmahuida, VIII Región, Chile. XIV Congreso Geológico Chileno, La Serena, 4 p.

[11] Aguirre, L., Hervé, F. and Godoy, E. (1972) Distribution of Metamorphic Facies in Chile-An Outline. Krystalinikum, 9, 7-19.

[12] Hervé, F. (1977) Petrology of the Crystalline Basement of the Nahuelbuta Mountains, South-Central Chile. In: Ishikawa, T. and Aguirre, L., Eds., Comparative Studies on the Geology of the Circum-Pacific Orogenic Belt in Japan and Chile, Japanese Society for the Promotion of Science, London, 1-52.

[13] Duhart, P., McDonough, M., Muñoz, J., Martin, M. and Villeneuve, M. (2001) El complejo metamórfico Bahía Mansa en la Cordillera de la Costa del centro-sur de Chile (39 $\left.30^{\prime}-42^{\circ} 00^{\prime} \mathrm{S}\right)$ : Geocronología K-Ar, 40Ar/39Ar y U-Pb e implicancias en la evolución del margen sur-occidental de Gondwana. Revista Geológica de Chile, 28, 179-208. https://doi.org/10.4067/S0716-02082001000200003

[14] Willner, A.P., Glodny, J., Gerya, T.V., Godoy, E. and Massonne, H. (2004) A Counterclockwise PTt-Path in High Pressure-Low Temperature Rocks from the Coastal Cordillera Accretionary Complex of South Central Chile: Constraints for the Earliest Stage of Subduction Mass Flow. Lithos, 73, 283-310.

https://doi.org/10.1016/j.lithos.2004.03.002

[15] Creixell, C., Lucassen, F., Franz, G., Vásquez, P. and Figueroa, O. (2002) Petrology of the Hualpén Stock: Evidence of Late Triassic Epizonal Plutonism at the Western Margin of Gondwana ( $\left.36^{\circ} 45^{\prime} \mathrm{S}, 73^{\circ} 10^{\prime} \mathrm{W}\right)$. International Symposium on Andean Geodynamics, Toulouse, 5, 167-170.

[16] Hervé, F., Munizaga, F., Parada, M.A., Brook, M., Pankhurst, R.J., Snelling, N.J. and Drake, R. (1988) Granitoids of the Coast Range of Central Chile: Geochronology and Geologic Setting. Journal of South American Earth Sciences, 1, 185-194. https://doi.org/10.1016/0895-9811(88)90036-3

[17] Hervé, F., Godoy, E., Parada, M.A., Ramos, V., Rapela, C., Mpodozis, C. and Davidson, J. (1987) A General View on the Chilean-Argentine Andes, with Emphasis on Their Early History. Circum Pacific Orogenic Belts and the Evolution of the Pacific Ocean Basin. Geodynamics Series, 18, 97-114. https://doi.org/10.1029/GD018p0097

[18] Hervé, F. (1994) The Southern Andes between $39^{\circ}$ and $44^{\circ} \mathrm{S}$ Latitude: The Geological Signature of a Transpressive Tectonic Regime Related to a Magmatic Arc. In: Reutter, K.J., Scheuber, E. and Wigger, P.J., Eds., Tectonics of the Southern Central Andes, Springer Verlag, Berlin, 243-248. https://doi.org/10.1007/978-3-642-77353-2_17

[19] Hervé, F., Munizaga, F., Montovani, M. and Hervé, M. (1976) Edades Rb/Sr neopaleozoicas del Basamento Cristalino de la Cordillera de Nahuelbuta. I Congreso Geológico Chileno, Santiago, 7 p.

[20] Lucassen, F., Franz, G., Creixell, C., Vásquez, P., Romer, R. and Figueroa, O. (2004) Distinguishing Crustal Recycling and Juvenile Addictions at Active Continental Margins: The Paleozoic to Recent Compositional Evolution of the Chilean Pacific Margin (36-41 ' S). Journal of South American Earth Sciences, 17, 103-119. https://doi.org/10.1016/j.jsames.2004.04.002

[21] Glodny, J., Echtler, H., Collao, S., Ardiles, M., Burón, P. and Figueroa, O. (2008) Differential Late Paleozoic Active Margin Evolution in South-Central Chile $\left(37^{\circ}\right.$ $40^{\circ}$ S) - The Lanalhue Fault Zone. Journal of South American Earth Sciences, 26, 397-411. https://doi.org/10.1016/j.jsames.2008.06.001 
[22] Ferraris, F. (1981) Avance geológico Hoja Los Ángeles-Angol, Región del Bío-Bío. Instituto de Investigaciones Geológicas, Santiago, Vol. 5, 26 p.

[23] Nielsen, S. (2005) The Triassic Santa Juana Formation at the Lower Biobío River, South-Central Chile. Journal of South American Earth Sciences, 19, 547-562. https://doi.org/10.1016/j.jsames.2005.06.002

[24] Salazar, C., Stinnesbeck, W. and Quinzio-Sinn, L.A. (2010) Ammonites from the Maastrichtian (Upper Cretaceous) Quiriquina Formation in Central Chile. Neues Jahrbuch Geologie und Paläontologie Abhandlungen, 257, 181-236. https://doi.org/10.1127/0077-7749/2010/0072

[25] Pineda, V. (1986) Evolución paleogeográfica de la cuenca sedimentaria CretácicoTerciaria de Arauco. In: Frutos, J., Oyarzún, R. and Pincheira, M., Eds., Geología y recursos minerales de Chile, Universidad de Concepción, Concepción, 375-390.

[26] Frutos, J. and Cisternas, M. (1994) Evolución tectónica de la Cuenca Terciaria de los Andes del Sur de Chile $\left(37^{\circ} 30^{\prime}-40^{\circ} 30^{\prime}\right.$ lat. S.). VII Congreso Geológico Chileno, Concepción, $5 \mathrm{p}$.

[27] Elgueta, S. and Arcos, R. (1993) Geología y modelo de sedimentación de la secuencia Cretácico-Terciaria de la Cuenca de Arauco. Empresa Nacional del Petróleo, Santiago, $32 \mathrm{p}$.

[28] Collao, S., Alfaro, G., Cecioni, A., González, A. and Quinzio, A. (2000) Evaluación de los Recursos Metálicos de la Región del BioBío, Chile. Universidad de Concepción, Concepción, 207 p.

[29] Stange, F., Helle, S. and Collao, S. (2018) Exploratory Potential for Gold Placer Deposits in the Coastal Range, BioBío Region, South-Central Chile. International Journal of Geosciences, 9, 635-657. https://doi.org/10.4236/ijg.2018.911038

[30] Biró, L. (1982) Revisión y redefinición de los "Estratos de Quiriquina", Campaniano-Maastrichtiano, en su localidad tipo en la Isla Quiriquina, 36 $35^{\prime}$ 'S, Chile, Sudamérica, con un perfil complementario en Cocholhue. III Congreso Geológico Chileno, Concepción, 35 p.

[31] Hervé, F. (1988) Late Paleozoic Subduction and Accretion in Southern Chile. Episodes, 11, 183-188.

[32] Rapela, C.W. and Pankhurst, R.J. (1992) The Granites of Northern Patagonia and the Gastre Fault System in Relation to the Break-Up of Gondwana. Geological Society of London, Special Publications, 68, 209-220. https://doi.org/10.1144/GSL.SP.1992.068.01.13

[33] Velásquez, R., Collao, S. and Figueroa, O. (2012) Zonación Mineralógica de la Pegmatita Poñen en el Batolito Costero del Sur, Región del Biobío-Chile. XIII Congreso Geológico Chileno, Antofagasta, 3 p.

[34] Kubatko, K.A., Helean, K., Navrotsky, A. and Burns, P. (2006) Thermodynamics of Uranyl Minerals: Enthalpies of Formation of Uranyl Oxide Hydrates. American Mineralogist, 91, 658-666. https://doi.org/10.2138/am.2006.1856

[35] Demartin, F., Pilati, T., Diella, V., Donzelli, S., Gentile, P. and Gramaccioli C.M. (1991) The Chemical Composition of Xenotime from Fissures and Pegmatites in the Alps. The Canadian Mineralogist, 29, 69-75.

[36] Guastoni, A., Nestola, F., Ferraris, C. and Parodi, G. (2012) Xenotime-(Y) and Sn-Rich Thortveitite in Miarolitic Pegmatites from Baveno, Southern Alps, Italy. Mineralogical Magazine, 76, 761-767. https://doi.org/10.1180/minmag.2012.076.3.23

[37] Taylor, M. and Ewing, R.C. (1978) The Crystal Structure of the $\mathrm{ThSiO}_{4}$ Polymorphs: 
Huttonite and Thorite. Acta Crystallographica, 34, 1074-1075. https://doi.org/10.1107/S0567740878004951

[38] Frondel, C. (1958) Systematic Mineralogy of Uranium and Thorium. U.S. Geological Survey Bulletin No. 1064, 208-211.

[39] Pracejus, B. (2008) The Ore Minerals under the Microscope: An Optical Guide. Elsevier, Amsterdam, 875 p.

[40] Klein, C. and Hurlburt Jr., C.S. (1993) Manual of Mineralogy. John Wiley and Sons Inc., New York, $681 \mathrm{p}$.

[41] Ramdohr, P. (1980) The Ore Minerals and Their Intergrowths. Pergamon Press, Oxford, $440 \mathrm{p}$.

[42] Ercit, T.S. (2002) The Mess That Is "Allanite". The Canadian Mineralogist, 40, 1411-1419. https://doi.org/10.2113/gscanmin.40.5.1411

[43] Rudnick, R.L. and Gao, S. (2004) Comparison of the Continental Crust. In: Rudnick, R.L., Ed., The Crust Treatise on Geochemistry, Vol. 3, Elsevier-Pergamon, Oxford, 1-64. https://doi.org/10.1016/B0-08-043751-6/03016-4

[44] Wall, F. (2014) Rare Earth Elements. In: Gunn, G., Ed., Critical Metals Handbook, Wiley-Blackwell, Hoboken, 312-339. https://doi.org/10.1002/9781118755341.ch13

[45] Long, K.R., Van Gosen, B.S., Foley, N.K. and Cordier, D. (2010) The Principal Rare Earth Elements Deposits of the United States-A Summary of Domestic Deposits and a Global Perspective. U.S. Geological Survey Scientific Investigations Report 2010-5220, 96 p. https://doi.org/10.3133/sir20105220

[46] Van Gosen, B.S., Verplanck, P.L., Seal, R.R., II, Long, K.R. and Gambogi, J. (2017) Rare-Earth Elements. In: Schulz, K.J., DeYoung, J.H., Jr., Seal, R.R. II and Bradley, D.C., Eds., Critical Mineral Resources of the United States-Economic and Environmental Geology and Prospects for Future Supply, U.S. Geological Survey Professional Paper 1802, O1-O31. https://doi.org/10.3133/pp1802O

[47] Smith, M.P., Moore, K., Kavecsánszki, D., Finch, A.A., Kynicky, J. and Wall, F. (2016) From Mantle to Critical Zone: A Review of Large and Giant Sized Deposits of the Rare Earth Elements. Geoscience Frontiers, 7, 315-334. https://doi.org/10.1016/j.gsf.2015.12.006

[48] Orris, G.J. and Grauch, R.I. (2002) Rare Earth Element Mines, Deposits, and Occurrences. U.S. Geological Survey Open-File Report, Tucson, 2-189. https://doi.org/10.3133/ofr02189

[49] Sengupta, D. and Van Gosen, B. (2016) Placer-Type Rare Earth Element Deposits. Reviews in Economic Geology, 18, 81-100. https://doi.org/10.1130/abs/2016AM-279551

[50] Teh, G.H. and Lokman, I. (2002) EPMA Characterization of Ilmenite from Amang of the Kinta and Klang Valleys, Peninsular Malaysia. Bulletin of the Geological Society of Malaysia, 45, 81-92. https://doi.org/10.7186/bgsm45200212

[51] Collao, S., Frutos, J., Helle, S. and Pincheira, M. (1982) Mineralogía y aspectos texturales de la fracción metálica de un paleoplacer y placer de playa de $\mathrm{Fe}-\mathrm{Ti}$, Región del Bio-Bio. III Congreso Geológico Chileno, 236-255.

[52] Force, E.R. (1991) Geology of Titanium-Mineral Deposits. Geological Society of America Special Paper 259, 112 p. https://doi.org/10.1130/SPE259-p1

[53] Angusamy, N., Loveson, V.J. and Rajamanickam, G.V. (2004) Zircon and Ilmenite from the Beach Placers of Southern Coast of Tamil Nadu, East Coast of India. Indian Journal of Marine Sciences, 33, 138-149. https://doi.org/10.1080/10641190600704350 
[54] Glodny, J., Lohrmann, J., Echtler, H., Gräfe, K., Seifert, W., Collao, S. and Figueroa, O. (2005) Internal Dynamics of a Paleoaccretionary Wedge: Insights from Combined Isotope Tectonochronology and Sandbox Modelling of the South-Central Chilean Forearc. Earth and Planetary Science Letters, 231, 23-39. https://doi.org/10.1016/j.epsl.2004.12.014

[55] Willner, A.P. (2005) Pressure-Temperature Evolution of an Upper Paleozoic Paired Metamorphic Belt in Central Chile ( $34^{\circ}-35^{\circ} 30^{\prime}$ S). Journal of Petrology, 46, 1805-1833. https://doi.org/10.1093/petrology/egi035

[56] Deckart, K., Hervé, F., Fanning, M., Ramírez, V., Calderón, M. and Godoy, E. (2014) U-Pb Geochronology and Hf-O Isotopes of Zircons from the Pennsylvanian Coastal Batholith, South-Central Chile. Andean Geology, 41, 49-82.

https://doi.org/10.5027/andgeoV41n1-a03

[57] Alarcón, A., Álvarez, F., Collao, S. and Hernández, L. (2018) Caracterización óptica y composicional de los minerales portadores de REE+Y, U, Th, en las pegmatitas Coyanmahuida y Poñén, Región del Biobío, Chile. XV Congreso Geológico Chileno, Concepción, 3 p.

[58] Roy, P.S. and Whitehouse, J. (2003) Changing Pliocene Sea Levels and Formation of Heavy Mineral Beach Placers in the Murray Basin, Southeastern Australia. Economic Geology, 98, 975-983. https://doi.org/10.2113/gsecongeo.98.5.975

[59] Hou, B., Frakes, L.A., Sandiford, M., Worrall, L., Keeling, J. and Alley, N.F. (2008) Cenozoic Eucla Basin and Associated Paleovalleys, Southern Australia-Climatic and Tectonic Influences on Landscape Evolution, Sedimentation and Heavy Mineral Accumulation. Sedimentary Geology, 203, 112-130. https://doi.org/10.1016/j.sedgeo.2007.11.005

[60] Hou, B., Keeling, J., Reid, A., Fairclough, M., Warland, I., Belousova, E., Frakes, L. and Hocking, R. (2011) Heavy Mineral Sands in the Eucla Basin, Southern Australia-Deposition and Province-Scale Prospectivity. Economic Geology, 106, 687-712. https://doi.org/10.2113/econgeo.106.4.687

[61] Roy, P.S., Whitehouse, J., Cowell, P.J. and Oakes, G. (2000) Mineral Sands Occurrences in the Murray Basin, Southeastern Australia. Economic Geology, 95, 11071128. https://doi.org/10.2113/95.5.1107

[62] Melnick, D., Bookhagen, B., Echtler, H. and Strecker, M. (2006) Coastal Deformation and Great Subduction Earthquakes, Isla Santa María, Chile ( $\left.37^{\circ} \mathrm{S}\right)$. Geological Society of America Bulletin, 118, 17 p. https://doi.org/10.1130/B25865 